\title{
Impacts of the Covid-19 pandemic on the supply chain of broiler chicken in Indonesia
}

\author{
Pria Sembada*, Arief Daryanto, and Silvia Dewi Sagita Andik \\ College of Vocational Studies, IPB University (Bogor Agricultural University), Jl. Kumbang No. 14 \\ Kampus IPB Cilibende 16128, Bogor, Indonesia
}

\begin{abstract}
The poultry sector in Indonesia faces complex challenges in the time of the Covid 19 pandemic. This pandemic disrupted the supply chain of broiler chickens. This study aims to identify impacts of Covid-19 on the broiler chicken supply chain. Data were collected using in-depth interviews and focus group discussions with actors in the broiler chicken business, breeders' associations, academics, experts, and the government. Also, secondary data was collected, including production data, demand data, and balance data. The data were analysed using the rich picture approach, supply chain analysis, and descriptive analysis. The results showed that accessibility and supply of production factors were hampered due to activity limitation policies and production control policies resulting in decreased production. Disruption in the distribution process also affects supply and demand. The decrease in demand for broiler chickens is very high. These factors might affect the fluctuation in the price of production factors and the selling price of the live birds at the farmer level. Issues due to a pandemic must be appropriately addressed and thoroughly as a mitigation effort in facing crises in the future. The right strategies need to be carried out comprehensively from the upstream, supply chain, and downstream levels. For instance, the partnership with the processing industries (or integrator), investments in the cold chain, and promotion would play an important role.
\end{abstract}

\section{Introduction}

The poultry sector in Indonesia plays an essential role in national economic development. Not only national economic development through the absorption of skilled labour and the creation of employment, especially in rural areas, this sector also plays a vital role in fulfilling community nutrition through the consumption of animal protein from eggs and chicken meat. In 2017, the contribution of broiler and native chicken to the total meat production in Indonesia was $71 \%$, and the remaining $29 \%$ was from other meat [1]. In the long term, the impact is that it can help reduce stunting rates in Indonesia.

However, this sector also faces complex challenges that must be resolved thoroughly and comprehensively at the upstream, supply chain, and downstream levels. In addition, the conditions of the Covid 19 pandemic since March 2020 caused additional shocks. The

\footnotetext{
* Corresponding author:sembadapria@apps.ipb.ac.id
} 
impact caused by this pandemic adds to the homework of the government, poultry business actors, breeders, academics, and every actor related to this industry. As it is known that this pandemic has a severe impact on all lines of economic activity, including agriculture and the livestock sub-sector [2, 3, 4].

This study aimed to identify the impact of the pandemic on the broiler chicken supply chain. Interestingly, only a few scientific studies and publications discuss the impact of the pandemic on the broiler chicken industry from the upstream, supply chain, and downstream sides in Indonesia. Once these impacts have been identified, the results can be used to formulate an effective strategy in resolving problems in this sector. Recommendations for solving the complex issues of poultry in Indonesia are expected for business actors and society.

\section{Method}

\subsection{Study design}

The scope of this study was national level. This research consisted of several stages, including literature study, development of in-depth interview guidelines, development of FGD guidelines, primary and secondary data collection, data analysis, and discussion. Indept interviews was conducted in Bogor from mid-August to early December 2020.

Literature study. This stage included searching for information from journals, books, online news, and so on as an effort to identify problems and business conditions for poultry in the period before and during the Covid 19 pandemic.

Development of in-depth interview guidelines. At this stage, the guidelines were arranged based on an outline and/or questions that can be used to extract information from sources to answer the research objectives. The guidelines contained the resource persons' identity and characteristics, business activities, aspects of livestock production, aspects of distribution and marketing, aspects of demand, and factors that affect poultry business activities during a pandemic.

Development of FGD guidelines. The guidelines were to obtain the experts' views and present the results of the identification at the literature study stage. The goal was to confirm or get input related to the answer to the purpose of this study.

Data collection. At this stage, primary data was collected through in-depth interviews and FGDs involving actors in the poultry business supply chain. Interviews and FGDs were conducted with representatives from the government (Ministry of Agriculture), representatives of academics, representatives of breeder's associations, representatives of the large, medium, and small scale business actors, as well as representatives of experts who play an essential role in the supply and demand analysis team. Apart from primary data, this study also used secondary data obtained from the Central Bureau of Statistics (Badan Pusat Statistik), the Ministry of Agriculture, breeders associations, and the supplydemand analysis team. Broiler production data wereobtained based on the DOC Final Stock (FS) production data approach which is calculated from the SHR (Setting Hatching Record) data. Demand data was obtained from BPS projections of the demand for chicken meat during the pandemic. The percentage change in price data was obtained using the following formula: change in price $=$ (price during the current month - price in the previous month) / price in the last month $\mathrm{x} 100$. 


\subsection{Data analysis}

After the data was collected, data analysis was performed using a rich picture, value chain analysis, and descriptive analysis. Rich picture was used to see complex issues as a whole [5]. Meanwhile, value chain and supply chain analysis were commonly used to identify channels of conditions in each chain $[6,7,-8]$. Tabulated data were presented in tables and figures using SPSS and Microsoft Excel software.

\section{Results and discussion}

\subsection{The disruption of broiler chicken supply chain during the pandemic}

Results showed that the Covid 19 pandemic caused a shock effect on the demand and supply activities of the broiler chicken business in Indonesia (Fig.1). From upstream to downstream, experiencing impacts to varying degrees. From the supply side, the Covid 19 pandemic has caused several countries to impose lockdowns. This situation has an impact on disrupting the supply of production factors whose raw materials come from imports. Furthermore, constraints on the supply of production factors such as feed ingredients in countries with restricted mobility (China, for instance) have made feed industry players seek suppliers from other countries. Economically, the impact is an increase in costs, which causes a slight increase in feed prices and a decrease in the profitability of broiler chicken entrepreneurs. According to the previous study [9], the Covid 19 pandemic has generally caused a decline in exports in China.

Besides feed, another important production factor is the availability and supply of DOC (Day Old Chicken). In Indonesia, the supply of DOC Final Stock (FS) broilers can be met from domestic breeding farms. However, through several integrator companies, Indonesia is still importing Hatching Egg Grand Parent Stock (HE GPS), which the government regulates. The supply and demand analysis team formed under the Ministry of Agriculture is tasked with helping to achieve a balance between supply and demand for broiler chicken's commodity in Indonesia. During the pandemic, the availability of broiler DOCs was still relatively high and was a projection from calculations in the previous two years when identifying the need to import GPS.

Apart from the availability of inputs, accessibility of inputs is also disrupted due to delays in the distribution process. The distribution of production inputs from the supplying country experiences delays in the distribution process due to restricted mobility. The distribution process has been delayed in Indonesia because several regions implement large-scale social restrictions (PSBB). However, distribution for several strategic sectors, such as foodstuffs, was allowed to continue operating. Delays in the distribution process have an impact on the poultry business in general. This circumstance was also a concern in other countries such as China. The study conducted by [3] confirmed that unwarranted restrictive policies significantly affect the country's agricultural production system. 


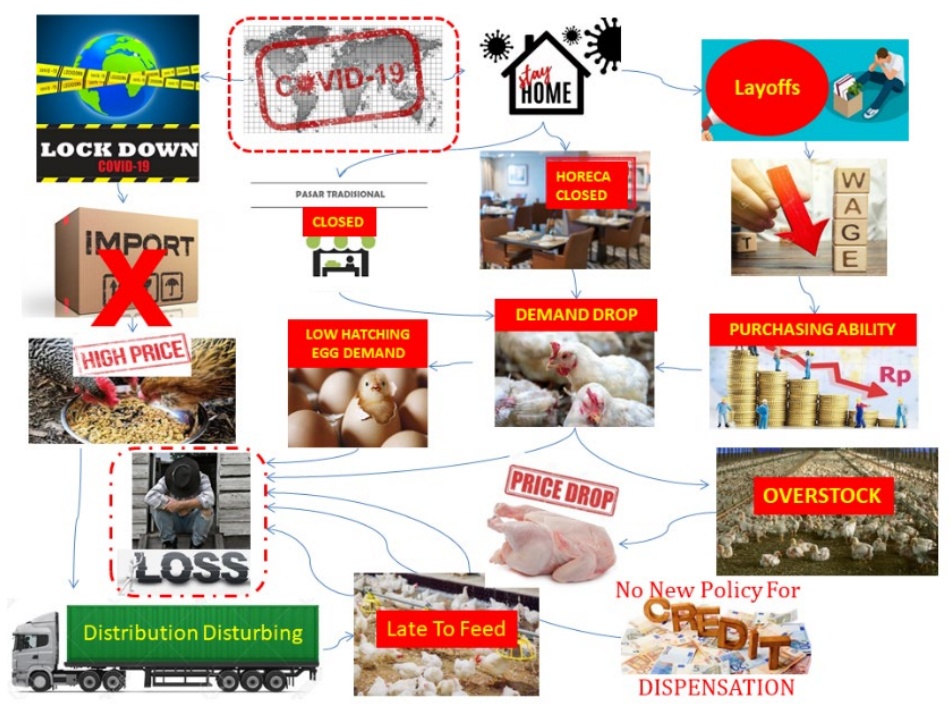

Fig. 1. Rich picture about the disruption of broiler chicken business during pandemic Covid 19

The Covid 19 pandemic had a more significant impact on the demand side. Demand decreased quite drastically, at least due to several main factors that have fallen peoples' income and the tendency of people to stay at home to reduce the risk of the spread of Covid 19. The increase in layoffs and unemployment and the decline in people's income caused people's purchasing power to decrease. As a result, the demand for chicken was decreasing. On the other hand, the tendency of people to stay at home caused the HORECA sector (hotels, restaurants, and cafes) to experience a decline in turnover.

Furthermore, the demand for broilers in the HORECA sector decreased drastically. Likewise, what happened in the early days of the pandemic when people reduced their shopping activities at traditional markets resulted in a decrease in demand for chicken meat in the form of the carcass (hot carcass). In 2019, traditional markets supplied $70 \%$ of foodstuffs in Indonesia, followed by mini markets $(23 \%)$ and supermarkets $(5 \%)$. The Large-Scale Social Restrictions Policy (PSBB) reduced the operating time of traditional markets. Many traditional markets have suffered losses due to a decrease in customers visiting the traditional markets.

In general, demand and production experienced shocks due to the Covid 19 pandemic on a different scale. The demand side had undergone a drastic decline while the production side has fluctuated. From small breeders to integrated companies, poultry business players suffered losses in the early days of the pandemic. Discussions with small-scale breeders (who have 80000 broilers) in partnership with the company through "makloon" obtained information on a decrease in livestock business income. This situation was due to decreased performance index (IP) at harvest time. It might be related to the decline in the quality of the feed supplied from the partners. However, with a partnership system, these farmers did not experience a loss, only a decrease in income. For medium-scale breeders with downstream business units, the Covid 19 pandemic required adjustments at the beginning of the pandemic, such as increasing cold storage capacity. The losses only occurred from April to June, and then after that, they stabilized again. The impact was more significant for large companies. One of the integrated companies in the financial statements as of September 30, 2020, experienced a decrease in total comprehensive income by almost 11 percent compared to the year before the pandemic (2019). This problem also occurred in other countries such as India. According to [10], this pandemic led to the adoption of a 
lockdown policy and was projected to have the potential to cost the country 3053 million USD.

\subsection{Production, needs, and balance}

Fig. 2 shows the trend of broiler chicken production in 2019 and 2020. Before the pandemic (2019), broiler production seemed to fluctuate, ranging from 254 thousand tons to 322 thousand tons. During the pandemic (March-December 2020), the production also appeared to fluctuate. Still, there was a reasonably drastic decline each month, especially in the early stages of the pandemic (June), and it was also projected to still reach its peak decline in December 2020. The highest production during the pandemic was in April 2020, which reached 287 thousand tons. The decline in production could be caused by several factors, including decreased demand, constrained supply of production factors, and government regulations (Circular issued by the PKH Director-General) related to controlling broiler chicken production by cutting HE, early rejections, and setting HE. This data also confirms the identification results regarding the impact of the pandemic from a supply perspective.

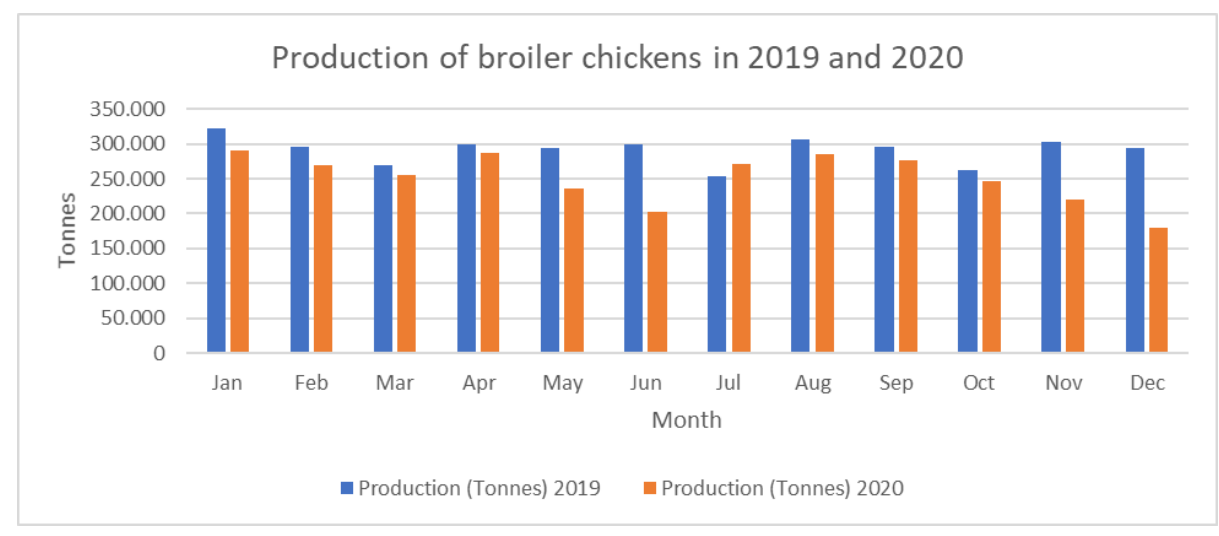

Fig. 2. Broiler Chicken Production in 2019 and 2020 (Source: Ministry of Agriculture, 2020)

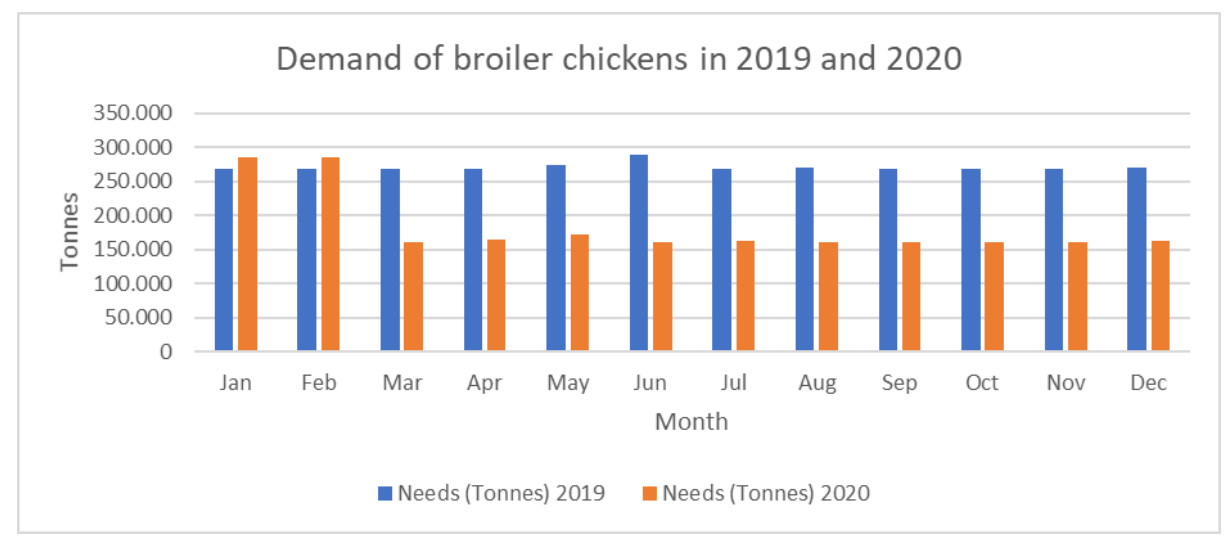

Fig. 3. The Demand of Broiler Chickens in 2019 and 2020 (Source: Ministry of Agriculture, 2020)

Apart from the production side, the demand side also experienced a drastic decline. This circumstance strengthens the findings in the rich picture related to the disruption of the poultry trade due to the Covid 19 pandemic. Since the beginning of the pandemic, the need 
for broiler chickens has fallen to 161 thousand tons (Fig. 3). In stark contrast to the year before the pandemic, the demand for broilers tended to be stable at 268 thousand tons to 288 thousand tons. As previously explained, several factors that led to falling demand include: reduced purchasing power, decreased demand from the hospitality sector, and closed or limited access to traditional markets. In addition, this decline may occur due to changes in food consumption behaviour by the community. Research conducted by [2] mentioned that there had been a change in food consumption trends in China during the pandemic. Consumption of meat and chicken had decreased quite drastically and had been replaced by vegetables, fruit, and other staple foodstuffs. However, discussions with one of the entrepreneurs in the integrated RPHU sector indicated that the level of sales in traditional markets was still relatively high and only affected the beginning of the pandemic.

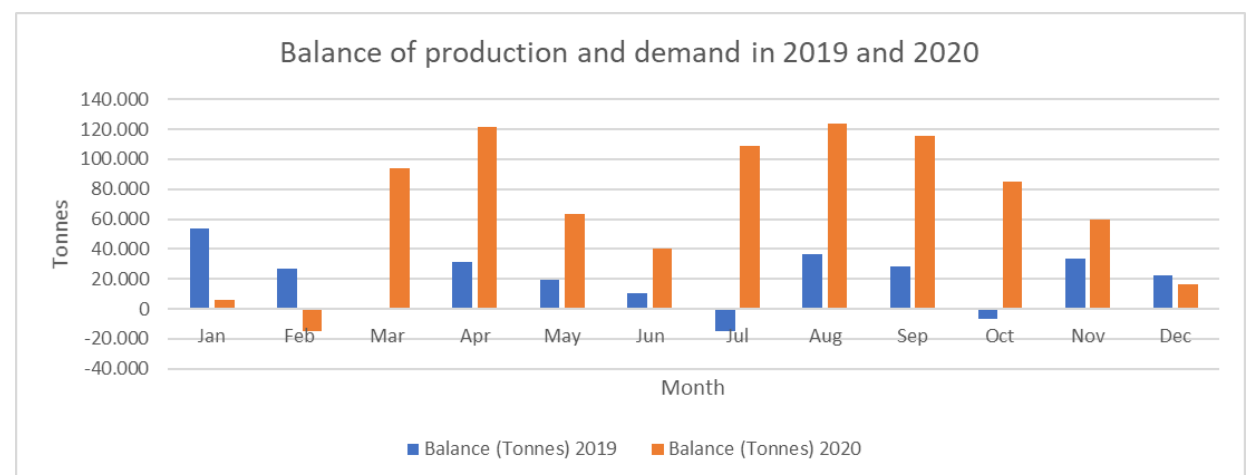

Fig. 4. Balance of production and demand for broiler chickens in 2019 and 2020 (Source: Ministry of Agriculture, 2020)

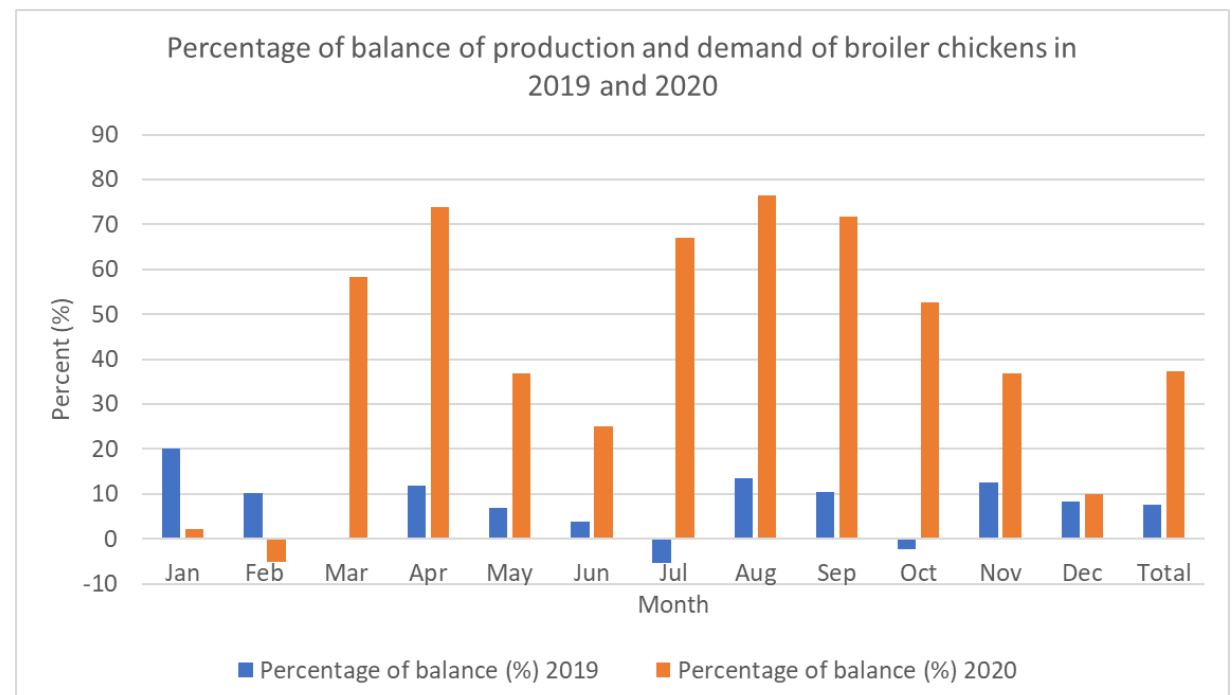

Fig. 5. Percentage of balance of production and demand of broiler chickens in 2019 and 2020 (Source: Ministry of Agriculture, 2020)

The trend in the balance of supply and demand for broiler chickens before and during the pandemic had a difference (Fig. 4). Before the pandemic, the balance sheet was in the range of - 14 thousand tons (July 2019), to the highest was 54 thousand tons (January 
2019). In other words, broiler production in July 2019 was less than the demand for that month and experienced a production deficit of 5.5 percent (Fig. 5). However, in January 2020, broiler chicken production experienced a relatively high surplus of 20 percent (Fig. 5). Meanwhile, a general excess of production ranged from 16 thousand to 94 thousand tons during a pandemic. This situation means that the production surplus ranged from 10 (projected in December 2020) to 76 percent (August 2020). According to the supply and demand analysis team, the best excess is around 10 percent used as a reserve to meet people's needs. If the excess is too large, it can also impact price volatility.

\subsection{Broiler price trends and production factors}

The results showed that the prices of production factors such as feed were relatively stable before and during the pandemic (Fig. 6). However, DOC prices have fluctuated even before the Covid 19 pandemic. DOC prices fell at 1470 IDR at the start of the pandemic (April) then fluctuated again until October 2020. Interestingly, there was a drastic increase in prices (almost 200 percent) (Table 1) from April to May 2020. In general, these price fluctuations might be attributed to a decrease in demand resulting in production adjustments at the farmer level. Thus, the need for DOCs has also decreased. However, DOC production in 2020 has been projected from the previous two years, so that DOC stocks are already high. In addition, government policies through SE production control directly or indirectly impact the availability and price stability of DOCs.

Fig. 6 showed the live bird price, and the main production costs (Harga Pokok Produksi-HPP) had always fluctuated from before to the time of the Covid 19 pandemic. What is interesting is that the main production costs were consistently above the live bird price. Live bird prices were above HPP only in May and June 2020. In other words, if only based on HPP and live bird prices, the farmers would suffer losses. These price fluctuations are a challenge that had occurred several years before the pandemic.

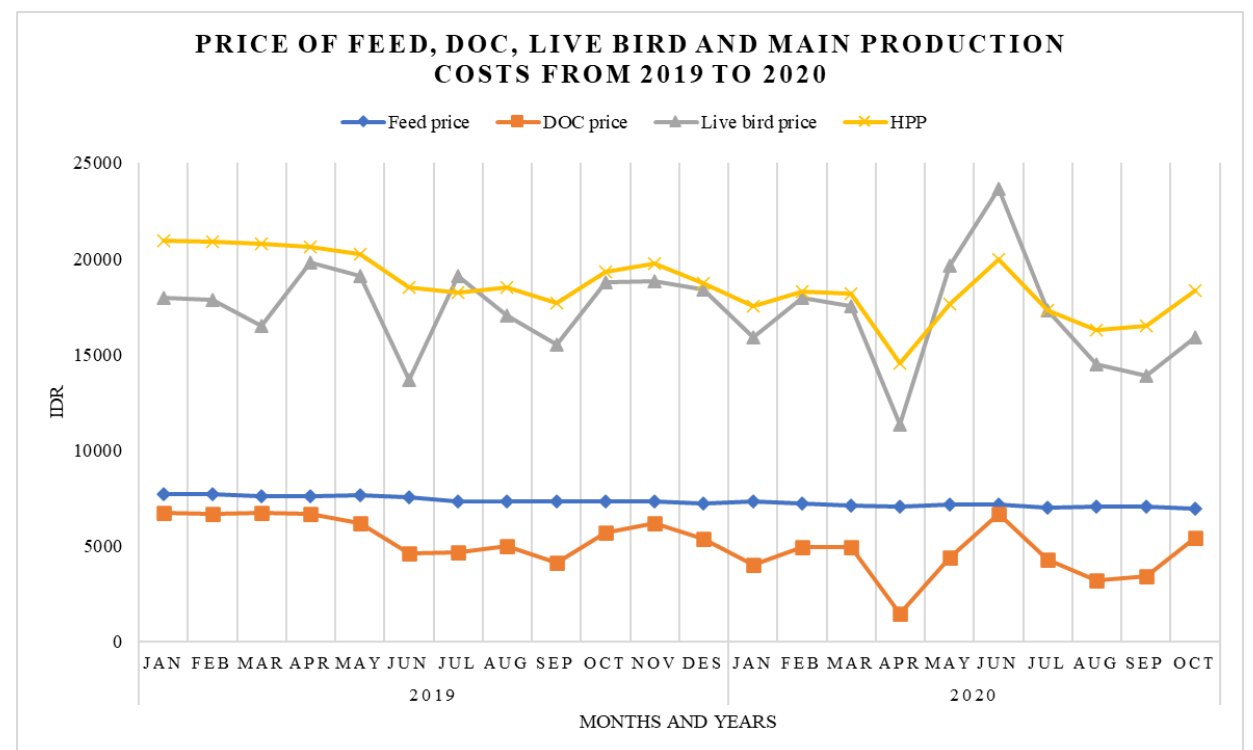

Fig. 6. Trends in the price of feed, DOC, live bird, and main production cost from 2019 to 2020. (Source: GOPAN, 2020) 
Table 1. Percentage change in the price of feed, DOC, live bird, and main production costs before and during the pandemic

\begin{tabular}{|c|c|c|c|c|c|}
\hline Year & $\begin{array}{c}\text { Percentage } \\
\text { change }\end{array}$ & $\begin{array}{l}\text { Feed } \\
\text { price }\end{array}$ & $\begin{array}{l}\text { DOC } \\
\text { price }\end{array}$ & $\begin{array}{l}\text { Live bird } \\
\text { price }\end{array}$ & $\begin{array}{c}\text { Main } \\
\text { production } \\
\text { cost }\end{array}$ \\
\hline \multirow{11}{*}{2019} & Feb & $-0,26$ & $-0,68$ & $-0,72$ & $-0,38$ \\
\hline & Mar & $-1,12$ & 0,70 & $-7,66$ & $-0,46$ \\
\hline & Apr & $-0,53$ & $-1,08$ & 20,22 & $-0,68$ \\
\hline & May & 0,74 & $-6,96$ & $-3,64$ & $-1,79$ \\
\hline & Jun & $-1,32$ & $-25,86$ & $-28,27$ & $-8,75$ \\
\hline & Jul & $-2,44$ & 1,65 & 39,34 & $-1,25$ \\
\hline & Aug & $-0,50$ & 6,57 & $-10,81$ & 1,35 \\
\hline & Sep & 0,30 & $-16,63$ & $-8,79$ & $-4,29$ \\
\hline & Oct & 0,14 & 37,65 & 21,04 & 8,93 \\
\hline & Nov & $-0,37$ & 8,75 & 0,28 & 2,36 \\
\hline & Dec & $-1,54$ & $-13,42$ & $-2,40$ & \begin{tabular}{|l|}
$-5,18$ \\
\end{tabular} \\
\hline \multirow{10}{*}{2020} & Jan & 1,71 & $-25,71$ & $-13,42$ & $-6,29$ \\
\hline & Feb & $-1,69$ & 23,19 & 12,87 & 4,10 \\
\hline & Mar & $-0,99$ & 0,79 & $-2,61$ & $-0,43$ \\
\hline & Apr & $-1,14$ & $\begin{array}{l}-70,38 \\
\end{array}$ & $-35,31$ & $-19,96$ \\
\hline & May & 1,46 & 197,76 & 73,68 & 21,15 \\
\hline & Jun & $-0,15$ & 53,05 & 20,19 & 13,07 \\
\hline & Jul & $-1,64$ & $-36,07$ & $-26,74$ & $-13,10$ \\
\hline & Aug & 0,17 & $-24,49$ & $-16,25$ & $-5,94$ \\
\hline & Sep & 0,28 & 5,72 & $-4,19$ & 1,34 \\
\hline & Oct & $-1,56$ & 59,23 & 14,30 & 11,15 \\
\hline
\end{tabular}

Source: GOPAN (2020) (data analyzed)

\subsection{Proposed strategies to mitigate crisis impact in the future}

Due to the Covid 19 pandemic, drastic changes made each actor in the broiler chicken trade chain take adaptive steps. Modifications were carried out by observing changes in community behaviour patterns which are also changing. Changes in behaviour in buying broiler chickens, from initially hot carcasses, began to shift to cold chain products. Changes in buying have occurred more or less, from originally coming directly to traditional markets to online shopping. Concern for product quality and safety is an important issue.

On the supply side, there was a shock due to the Covid 19 pandemic, such as decreased production even though the surplus was still relatively high compared to demand, fluctuations in feed and DOC prices, and high cost of production to produce live birds. Farmers could suffer losses if they only focus on selling live birds, given that the price of the live bird has always been below the cost of production for at least the last two years. 
The partnership with the poultry industries would be an option to minimize the risk during a crisis. The availability of DOC FS that can be projected fora long time needs attention to get the best strategy in managing the balance between production and demand. One of them is the disclosure of information from the breeding farms so that the accuracy of projections would be better. In addition, with the changing behaviour of consumers who are starting to pay attention to the quality and safety of the chickens consumed, it is necessary to carry out continuous guidance and monitoring related to Good Farming Practices, biosecurity, and animal welfare.

From the supply chain aspect, downstream needs to be considered carefully. Investments in cold chains (cold storage, blast freezers, and temperature-controlled vehicles) need to be made by companies and the government in facilitating farmers so that the focus of sales can shift from live birds to products with added value. As outlined earlier, a sales focus on the live bird can be a potential disadvantage for breeders.

On the demand aspect, to increase the enthusiasm of breeders in selling their products, not in the form of live birds, the promotion of chicken meat in either frozen or chilled form or processed form is essential. The existence of the Covid 19 pandemic can indirectly accelerate changes in consumer behaviour in consuming processed or frozen products. It can also anticipate fluctuating prices. In addition, the use of technology through ecommerce needs to be encouraged to maximize farmer profits without burdening consumers by shortening the marketing chain.

\section{Conclusion}

The poultry sector, especially broiler chickens, was significantly affected by the Covid 19 pandemic. This pandemic disrupted the supply chain of broiler chickens. On the supply side, accessibility and supply of production factors were hampered due to the activity limitation policy - also, production control policy resulting in a decline in production. From the supply chain side, disruption in the distribution process also affects supply and demand. From the demand side, the scale of shocks is the highest because the decrease in demand for broilers is very high. Some of these factors might be related to the price fluctuation of production factors and the selling price of the live bird at the farmer level. Live bird prices, which are always below the main production costs, are also a classic problem that needs to be resolved. Issues due to a pandemic must be adequately addressed and thoroughly to face crises in the future. The right strategy needs to be carried out comprehensively from the upstream, supply chain, and downstream levels.

Acknowledgement. The authors gratefully acknowledge Sekolah Vokasi (IPB University), who funded this study. We are also thankful to the farmers and the poultry industries and its distributors, suppliers and consumers for their cooperation during the study

\section{References}

1. Badan Pusat Statistik, Statistik Peternakan 2018. Jakarta, (2018)

2. P. Jia, COINLICS. 9 (2021)

3. M. Pu, Y. Zhong, Glob. Food Secur. 26, 100409. https://doi.org/10.1016/ j.gfs.2020.100409 (2020)

4. T. J. Richards, B. Rickard, Can. J. Agric. Econ. Can. Agroeconomie.68, 189-194. https://doi.org/10.1111/cjag.12231 (2020)

5. T. Berg, R. Pooley, Rich Pictures: A valuable means to explore complex IS issues $\mathbf{1 3}$ (2012) 
6. A. P. Karpriana, Y. A. Tribudi, Tata niaga pemasaran ayam pedaging pola mandiri di Kecamatan Rasau Jaya Kabupaten Kubu Raya Kalimantan Barat 4 (2019)

7. U. Priyadi, I.Susantun, A. S.Dewanta, Analisis distribusi ayam broiler di propinsi Daerah Istimewa Yogyakarta 9, 13 (2004)

8. V. S. Rumimpunu, I. D.Palandeng, J. J.Pondaag, Analisis rantai pasok ayam pedaging pada peternakan waruga Desa Lolah Kecamatan Tombariri Timur, Kabupaten Minahasa. 10 (2018)

9. B. Lin, Y. Y. Zhang, Impact of the COVID-19 pandemic on agricultural exports. J. Integr. Agric. 19, 2937-2945. (2020)

10. G. Kolluri, J. S. Tyagi, P. V. K. Sasidhar, Research Note: Indian Poultry Industry in the Era of COVID-19: A Situation Analysis Report. Poult. Sci. S0032579120308579. (2020) 